\title{
The patient and the relation between power-knowledge and care by nursing professionals ${ }^{a}$
}

O paciente e as relações de poder-saber cuidar dos profissionais de enfermagem

El paciente y las relaciones de poder-saber cuidar de los profissionales de enfermería

Marina Kelly Santos Baptista ${ }^{1}$

Regina Maria dos Santos ${ }^{1}$

Sebastião Junior Henrique Duarte ${ }^{2}$

Isabel Comassetto ${ }^{1}$

Maria Cristina Soares Figueiredo Trezza ${ }^{1}$

1. Universidade Federal de Alagoas.

Maceió, AL, Brasil.

2. Universidade Federal de Mato Grosso do

Sul. Campo Grande, MS, Brasil.
Corresponding author:

Marina Kelly Santos Baptista.

E-mail: marina.ksbaptista@gmail.com

Submitted on $03 / 15 / 2017$

Accepted on 06/15/2017.

DOI: 10.1590/2177-9465-EAN-2017-0064

\section{Abstract}

This is a study whose objective was to analyze, in the discourse of hospitalized patients, how the power of knowledge is revealed in Nursing care relations. It was developed in the qualitative perspective, having as theoretical reference the concept of power issued by Michel Foucault. The data were collected between August and December 2015 and the participants were 16 patients hospitalized in the medical and surgical clinics of a university hospital, who had the speech recorded through a semi-structured interview, after approval of the ethics committee under Opinion No. 1189934. In order to analyze the data we used the system of differentiations developed by Foucault. The results showed that the professionals exert power by the highly specialized professiona knowledge and that they know what they do, so they send and control the accomplishment of the care, leading the patient to submission. It concludes that the exercise of the power to care must be based on the observance of ethical and bioethical principles.

Keywords: Nursing; Power; Nursing-patient relationships; ethic.

\section{Resumo}

Estudo cujo objetivo foi analisar, no discurso de pacientes internados, como o poder do saber se revela nas relações de cuidado de Enfermagem. Foi desenvolvido na perspectiva qualitativa, tendo como referencial teórico o conceito de poder emitido por Miche Foucault. A coleta dos dados se deu entre agosto e dezembro de 2015 e os participantes foram 16 pacientes internados nas clínicas médica e cirúrgica de um hospital universitário, os quais tiveram o discurso gravado mediante entrevista semiestruturada, após aprovação do comitê de ética sob Parecer oํ 1189934. Para analisar os dados se utilizou o sistema de diferenciações desenvolvido por Foucault. Os resultados mostraram que os profissionais exercem poder pelo saber profissional altamente especializado e que eles sabem o que fazem, por isso mandam e controlam a realização dos cuidados, conduzindo o paciente à submissão. Conclui que o exercício do poder de cuidar deve ser balizado pela observância dos princípios éticos e bioéticos.

Palavras-chave: Enfermagem; Poder; Relações Enfermeiro-paciente; Ética.

\section{REsumen}

Estudio cuyo objetivo fue analizar, en el discurso de pacientes internados, como el poder del saber se revela en las relaciones de cuidado de Enfermería. Fue desarrollado desde una perspectiva cualitativa, teniendo como referencial teórico el concepto de poder emitido por Michel Foucault. El muestreo de los datos ocurrió entre agosto y diciembre de 2015 y los participantes fueron 16 pacientes internados en las clínicas médica y quirúrgica de un hospital universitario y sus discursos grabados mediante una entrevista semiestructurada, después del estudio haber sido aprobado por el comité de ética con el Parecer no 1189934 Para analizar los datos se utilizó el sistema de diferenciaciones desarrollado por Foucault. Los resultados mostraron que los profesionales ejercen poder por el saber profesional altamente especializado y como ellos saben lo que hacen, mandan y controlan la realización de los cuidados, sometiendo al paciente. Se concluye que el ejercicio de poder del cuidar debe ser marcado por la observación de los principios éticos y bioéticos.

Palabras clave: Enfermería; Poder; Relaciones Enfermero-paciente; Ética. 


\section{INTRODUCTION}

In Brazil, Nursing practice is regulated by Law No. 7,498, of June $26,1986,{ }^{1}$ and professionals must respect the code of ethics whose preamble defines the profession as:

[...] a specific component of scientific and technical knowledge constructed and reproduced by a set of social, ethical and political practices that are carried out through teaching, research and assistance. It is performed in the provision of services to the person, family and community, in their context and life circumstances. ${ }^{2}$

As the provision of services, nursing practice is placed in the working world, which takes place in a nursing care relationship, where the people assisted by nursing professionals are susceptible to the development of power relations in the care process, especially when the degree of dependence is high and the person's freedom to intervene in care is diminished. In this research it is understood that the nursing professional and the person cared for make up a social group and accept the idea defended by Foucault that every human grouping will always be surrounded by power relations, since the existence of this type of relationship is coexistent with social life, corroborating the thought that "a society without relations of power can only be an abstraction".3,4:244

Thus, the hospital is taken as a space where vertical relations of dependence between professional and cared person are established, in which the technical-scientific knowledge surpasses the subjectivity of the patient, being able to confer to this relation some exercise of power of the professional over the individual being cared for. ${ }^{5}$ This is because this environment was portrayed as a place of constant vigilance, where there is the dissemination of beliefs and social practices that inhibit the practice of autonomy in the face of illness, pain and death. ${ }^{6}$ For this reason, in this study, the hospitalized person, taking into account the position he/she occupies in the relationship of care, is called the patient.

At this juncture, the damage caused by the presence of a disease is universal, not limited to a given space or even a time, but assumes a very clear and distinct existential nature in diverse contexts. The experience of a crisis situation, motivated by the disease, eliminates from patients their character of aptitude to control their body, their feelings, and there is imprecision as to their future, as well as to carry out their social roles, thus affecting their capacity to exercise their rights and influence their decisions about care, leaving them in a position of dependence and inferiority before others. ${ }^{7}$

As far as science and technology are concerned, in the health field there is growing concern among professionals in order to improve their knowledge, promoting their improvement and, consequently, increasing their responsibilities regarding the level and quality of care provided by them. ${ }^{8}$ However, such care practices, and the act of care itself, have suffered - and suffer
- influence from the hegemonic biomedical model still present, both in health institutions and in vocational training institutions. ${ }^{9}$ This scenario leads nursing actions towards a practice guided by the disease, disregarding the experience of the person in need of care.

A study carried out in the countryside of Rio Grande do Sul, involving people with stomas, showed that, in order to care for, the nurse needs relationships that establish proximity between the subjects and culminate with mutual interactive processes, in which dialogue and contact must be valued and always based on ethics and respect for the condition of being as a subject of rights, desires and knowledge. ${ }^{10}$ On the other hand, a study carried out with nurses of an Intensive Care Unit in Goiânia, GO, concluded that health professionals claim to hold the legitimacy of the knowledge to offer contemporary technologies to their patients, fomenting space for the overvaluation of technology to the detriment of the assistance human character, ${ }^{11}$ stating that the practice of power and human care are still based on this technical-scientific paradigm of modernity. ${ }^{12}$

The literature recognizes that nurses have an important role in the health team. This professional is responsible for providing quality care to people through the use of technological, logistical and human resources, including the development of coordination, assistance, education and research activities. ${ }^{13}$ In this context, a bibliographic study showed that It is important to have knowledge of the principles of good ethical practice and to have resources available to assess merit, risks and social issues, ${ }^{14}$ which is an applicable recommendation in every nursing care relationship, in the specificity of each person.

It is understood that technical and scientific knowledge is essential for the practice of professional care and therefore inseparable both from practice and norms that regulate professional relations, generating a discourse admitted as truth and described as a relation of knowledge/power, through which one can exercise his own power. ${ }^{15}$ Foucault's thoughts anchors this statement when he clarifies that the coexistence between institutional regulatory norms - professional regiment and health institutions regiment - and patient protection legislation, both arising from power and knowledge games, are constituted as discipline power devices, through which power relations between professionals and patients are materialized. ${ }^{3}$

Thus, technicity and highly specialized knowledge contribute greatly to the reduction of individuals to a merely nosological classification, marked by the emphasis given to the nature and cure of the disease, and by the reduction of care to a consumer good. ${ }^{16}$ In this circumstance, it is inevitable that the person undergoes a process of massification or: "the individual loses his own identity and begins to assume the identification of the disease that invades his entire spatial, temporal and relational field," 17:141 suppressing the human character in the relationship between the individual who provides care and the individual who receives it.

Some authors argue that, because they are holders of specific knowledge, health professionals have developed a 
stereotyped conception in which the patients are beings devoid of knowledge. For this reason, they consider them incapable of understanding what happens in their bodies, relegating them to the category of objects submissive to professional care and reaffirming patients as object, with the risk of constructing heteronomy as "social iatrogenesis" characterized by the dissemination of the role of patient as a passive and authority-dependent behavior. ${ }^{18,19}$ This conception corroborates the idea presented in the book 'Patient and Person: interpersonal skills in nursing', which states that this circumstance highlights the power that health professionals hold. ${ }^{20}$

According to Weiss and Tappen, conceptions of power in nursing, in the past and today, treat the subject in a generic way, conceiving it as something that influences, controls or domains something or someone, manipulating it socially. ${ }^{21}$ It is also based on the appreciation of the social recognition of the profession, as a primary function of society, which, in itself, constitutes a declaration of the power of Nursing as a health profession, and to this power, which derives from its professional code, the power of its knowledge, which, when establishing itself as specific knowledge, produces actions of power.

This statement is based in Foucault's idea that knowledge and power are involved in a mutual way to the point that any exercise of power continually creates objects of knowledge, which are manipulable and transform into knowledge itself, and then in power again, in a cycle so complex that one is conditioning and conditioned by the other. ${ }^{22}$ Observing the scenario exposed by the literature on the power contained in Nursing knowledge, there is no doubt that care exists in a field that excels in the use of science, technology and human experience, aiming at ceasing and eradicating the pathological process, demonstrating a connection with the biomedical model. However, nursing care must go beyond the pathological process and also establish itself as a means of promoting health and quality of life for patients. ${ }^{23}$

Thus, it is through the narrative of the experience that one can have contact with the feelings and meanings that it arouses and, in this sense, it is accepted that the discourse of the subject who goes through the experience makes it known and the analysis of this discourse is the verbal expression of the experience. Therefore, in the line in which the study was conducted, the subject's discourse reveals the exercise of power in nursing care relationships, within which the empowerment conferred by professional knowledge is isolated. With regard to the patient's experience and how it can foster the resources needed to understand the subject matter discussed here, it is essential to understand that the patient's discourse is like the extension of a truth that is originated before the subject itself, ${ }^{24}$ constituting a set of propositions that acquire veridical character, beginning to compose acceptable principles of behavior. ${ }^{4}$

In this perspective, Foucault affirms that discursive production does not occur randomly, but is permeated by the power relations that produce it, giving the discourse the character of occurrence, since it materializes in the social practices of the subjects, and produces real effects, among which this study includes the practice of nursing care..$^{25}$ Thus, the following guiding question arises: How does the discourse of patients reveal the power impressed by power-knowledge in nursing? And, as an objective, the power of knowledge revealed in nursing care relations must be analyzed in the discourse of inpatients.

\section{METHODOLOGY}

This is a descriptive and analytical study, using a qualitative approach, which was based on the medical and surgical clinics of a teaching hospital in Maceió, Alagoas. It was performed between August and December 2015, with the participation of 16 patients of both sexes, who met the following selection criteria: to be at least 18 years old; minimal hospitalization time of 72 hours; be lucid and responsive; be classified as a patient with intermediate or semi-intensive care needs. Patients using nasal or oral probes and carrying any type of transmissible infection were not included.

A total of 137 inpatients were selected in the chosen sectors of the institution. In these, the Perroca and Gaidzinski patient classification instrument was applied, ${ }^{26}$ resulting in a total of 35 patients classified as intermediate and semi-intensive care. These were individually addressed on unit premises and were invited to participate, but only 16 expressed a desire to contribute to the survey. It is worth mentioning that this process does not detract from the experience of the other subjects, but it seeks those who depend more on nursing care to strengthen the discussion of this study.

Among the 16 informants, there were an equivalent number of men and women, whose ages varied between 22 and 80 years, and $68.75 \%$ of them were between 42 and 59 years of age; a variety of diagnoses were also observed among them, with predominance of neoplasms of several organs. The group of participants presented hospitalization time ranging from 03 to 120 days, with an average time of approximately 39 days. All had companions, except for two participants. The application of the Perroca and Gaidzinski instrument ${ }^{26}$ classified 15 of them as intermediate care and only one was classified as semi-intensive care. Based on these characterization data, it is understood that all interviewees experienced nursing care relationships, with different levels of dependency, guaranteeing reliability, trustworthiness and ownership of their narratives.

After clarifying the objectives of the study, and after consent, permission was requested for recording the conversation and signing the Term of Free and Informed Consent. In addition, the information was produced by conducting semi-structured interviews with each of the 16 informants, who answered the following questions: 1 - Could you tell me how this experience of being hospitalized is? 2 - Could you describe your impressions on the care received from the nurses?

The production of information was completed by saturation, obtained when the feeling of closure was outlined in the interview exam, that is, the new data provided repeated information. It was also adopted to declare the saturation of the data, the appreciation of two studies ${ }^{b}$, through which the data were saturated with 11 and 16 participants, respectively. 
The research project was approved by the Ethics Committee in Research of the Federal University of Alagoas, in August of 2015, under the substantiated Opinion No. 1189934 and CAAE No. 45801615.3.0000.5013. The written consent of the institution for data collection was obtained. It is noteworthy that, during the interviews, privacy was preserved while obtaining the information, as listening was restricted to the binomial interviewers/interviewees. Interlocutions from the patient interviews are identified as P1, [...] P16.

After being captured, the speeches were faithfully transcribed in the form of a report, read exhaustively, then cut out by repetition among the participants. Then, what Foucault called the system of differentiations, that is, the factors that point to the conditions of the exercise of power, was undertaken. ${ }^{27}$ Synthetically, this system states that both the differences between actors and those conditioned by factors external to human relations are what determine and influence the exercise of power. Thus, this system is taken as a way of analyzing these relations and determining what allows acting on the action of others.

However, it is necessary to consider that this study made use of the discourse of patients as the main means for obtaining the information and for its capacity to reveal the experience and the history of each patient admitted at the hospital. Then, an inter-relation was made between the proposed system and the elements found in the patients' speeches. In this context, it is fundamental to consider three points in this interrelationship: the first point is related to the scenario in which the actions take place, that is, if this scenario is governed by norms and routines, which by themselves constitute a form of action on the action of others that are inserted in this context; the second point is associated with the subject and the meaning that is attributed to the given relation; and the third point refers to the reading and interpretation that this subject makes of the posture or actions employed by the other in the dynamics of the relationship.

From the points presented, the categorization of the information was carried out. Such information was discussed in the light of the concepts of Freedom and Power Relations according to the French philosopher Michel Foucault. Following this reasoning, the scrutiny of each testimony made it possible to identify the category Power-Knowledge in nursing care relations, and three subcategories: they know why they do; they command; they control.

\section{ANALYSIS AND DISCUSSION OF RESULTS}

\section{Power-knowledge in nursing care relation}

Participants' speeches, with the exception of P9 and P11, show that professionals, in addition to complying with rules and routines, decide everything about care because they know what needs to be done and make or have patients do, such as, for example, they know the importance of hygiene, they tell patients to them bathe or bathe those who are bedridden. The speech of P7 exemplifies it:
[...] You just arrive and start doing it [...] it is not very good for the person; it leads the person to come and say something [...] But I did nothing [...] (P7).

The Power of Knowledge and the way it unfolded in other mechanisms of power reaffirms Foucault's conception that "[...] power and knowledge are directly involved; that there is no relation of power without a correlative constitution of a field of knowledge, nor to know that it is not considered and does not constitute, at the same time, relations of power."28:30 At this juncture, the discourses of the 16 participants made it possible to establish a line of occurrences, which demonstrated the power relations generated from the materialization of power-knowledge in nursing care relations, evidencing a circuit that was translated "they know - they command - they do", whose components are presented individually.

\section{They know}

When participants justified the nursing staff's ability to care for somebody or have someone provide some care, by saying that "they know what they are doing", they are giving meaning to the order and reinforcing the discipline imposed by the hospital routine. Thus, "they know" means recognizing that they "can" because they know how the system works, they know how treatment develops and they "only want what is good for you." For this reason, they make others obey them without many questions:

There, we don't have what we want, because they know what they do, you know? (P7)

Foucault idealizes knowledge/power so that knowledge and power are mutually involved to the point that the least exercise of power generates objects of knowledge that are always manipulated and become knowledge itself, and this becomes power again, in a complex chain in which one is conditioning and conditioned by the other. ${ }^{22}$ Thus, for him, knowledge is allied to the relation of power. This is explained by his idea that, over time, the human being was constituted through power, because, as the discourses were formed, what was considered true and correct, that is, absolute, came exactly from the speeches of the authorities, whether political, economic, or even scientific.

In this point of view, Michel Foucault presents the concept of episteme as "the set of relations that can, at a given time, unite discursive practices that give rise to epistemological figures, sciences and, eventually, formalized systems."29:214 Thus, understanding the scientific knowledge of nursing professionals as episteme, it is possible to see, in the speeches of the participants, the assumption of the nurse's speech as an unalterable truth within the context that is the focus of this study:

Also, we can't mix things up, because there they are professionals. (P1) 
This interpretation is also endorsed by the following participants:

\section{[...] Here, you have to put yourself into the hands of professionals. (P3)}

Yeah, they're doing it anyway; I have to let them do it because they have to do it anyway. They know what they are doing, right? (P5)

When the taking of the discourse of nursing is considered an unprecedented truth, it is necessary to understand that, like knowledge, there is no truth without power, which means that truth is produced by the relations that are maintained with power". ${ }^{3}$ To this fact, Foucault argues that knowledge ascribes authority and truth value to power, serving as its conducting element. ${ }^{29}$ At this juncture, although Foucault's thought does not present discourse as immutable, it is a historical and social construct. ${ }^{29}$ Thus, nursing knowledge is built on the basis of care; therefore, for patients, nurses are holders of knowledge for the act of care and, for this reason, they are submitted to power and knowledge both by need or dependency, and by the authority of the professional discourse and the truth that power imprints on it.

\section{They are in charge}

It was with this phrase that the participants expressed themselves when they received orders from the Nursing professionals to develop self-care activities, such as referral and supervision of hygienic care, changing clothes and dispensing of visitors in periods when they were not bedridden with a high degree of dependency. The command has meant for them an order of someone knows what to say and that that it is prudent to obey and to comply:

[...] We would arrive at the door and they would say: "To bed! Sick people should be in bed." (P7)

Analyzing the context presented, in which nursing professionals have in their speeches an authority printed by the truth produced by the power-knowledge games, it is worth reporting that the premise is added that nursing professionals are the only ones who have the knowledge for the practice of care, since this is the focus of their actions. ${ }^{30,31}$ This idea is anchored in Foucault when he says that the discourse that commands society is always the discourse of those who hold knowledge. Moreover, he further asserts that one side of this power relationship will always belong to that which is continually determined by the ideas coming from the 'superiors', in other words, by the class that ideologically dominates a given society. ${ }^{25}$

In contextualizing this concept and applying it to the hospital environment and to the relationship between nursing professionals and patients, there is a conjugation in which the patient is dominated by the discourse of the Nursing professional, as seen in the following statements:
They said "this is my job; I have to do it and that's it." (P2)

They say, "Yes, it hurts this way, so you have to turn around," then I say, "Please, come slowly because you're going to hurt me," then they say "No, you have to turn around! You have to turn around!", then they end up hurting me (P6).

From the highlighted speeches, one can perceive the presence of a coercive force coming from orders or commands that limit the possibility of voluntary action on the part of the patient. ${ }^{32}$ For this reason Foucault says that the body is trapped inside very tight powers, imposing limitations, prohibitions or obligations. He also affirms that these powers pervade every social form, modifying and transforming the conduct of individuals,${ }^{31}$ which are subjected to what the author has called "general formulas of domination," making it the object and target of power. $28: 133$ In nursing, two of the formulas are supervision and control. The speech of P4 clearly shows how this interpretation corresponds to the reality of caring relationships:

[...] And even if I could walk, I wouldn't go, because they wouldn't let me. (P4),

This is also expressed in the following lines:

There are people you can talk to on the same level, but there are others who get to you and make it clear: "I' $m$ the professional and you're just the patient, so be quiet and accept what I say" (P10);

There is no freedom, because we are at the mercy of whoever is willing to assist you at that moment [...] then, you have almost no autonomy over anything! [...] (P10);

If I have to be submissive to any professional other than the ones I already know, every situation will always be imposed and never proposed. The only thing I only can do is to comply [...] (P10);

[...] Sometimes you want to take a shower, but you can't because he says "you're only going to go when it's your turn (P15).

Another situation evidenced was that the non-sharing information between professionals and patients is an appropriate arrangement for the exercise of coercive power, since it hinders informed consent and can lead patients in the direction of an act of agreement with a perspective other than their own, adopting attitudes that are often contrary to their convictions..$^{33}$ In this light, coercive power applies to society in different ways, as Foucault puts it: a calculated manipulation of the gestures and behaviors by which one can have dominion over others, "not simply to do what one wants, but to operate as they want." $28: 133$ The following statements allow one to observe this conjunction: 
The nurse, the Nursing technician, before giving a medicine, he has to say it, because one day they will deal with people without any explanation and it may even be dangerous [...] (P3)

There we can't have what we want; they don't tell us anything, so they must know what they do, right? (P7)

How is that? What I say is of no use [...] they are the ones know what to do, since they don't say anything and what we say is not worth anything (P6)

People barely say what you are taking [...] They don't give me information as to how I am [...] I've been here for 11 days and just came to know something about my health two or three days ago [...] Nursing didn't give me any information, but every day they come here saying "you have to do this, you have to do that, because it will be better for you" (P8)

I would ask it there and here too, because I didn't know and because they didn't tell me it either. It seems they are afraid of us reacting in a way that they don't want (P12).

When looking at this point of view, it is verified that, in the hospital scope, many of those who seek care are fragile and want to find support and care in this environment. Under these conditions, it is common to ignore patients' concerns and coerce them to accept the proposed treatment. Thus, feeling coerced during hospitalization means, for patients to realize that they had no influence, control or choice, confirming, through the above to this point, that exercising power may affect the conduct of the others' actions. ${ }^{33,34}$

\section{They control it}

By completing the power exercise circuit in Nursing care relationships, participants admitted that if they are not able to take care of themselves, the professionals can do it for them, according to what their knowledge determines to be done. In this process, they do not always say something to patients or ask whether they accept that care and, in this way, they exercise the power to care according to their perspective and not the patients':

They would come in and say, "Let's take a shower." So they would start taking off my clothes and said "help me out" [...] (P6)

Ah! It's really bad... the nurse comes, puts the bedpan, you know? Then you urinate [...] it's awful! It's a bad feeling [...] too bad! (P14).

In order to present the dynamics of the control exercised by the Nursing professionals on patients, it is necessary to take into account, firstly, the environment in which this practice is carried out. Thus, in this discussion, it is necessary to insert the hospital as an institution, which historically constituted and legitimized itself as a space where the exercise of power is materialized..$^{35}$
In the book "Asylums, Prisons and Convents", Goffman brings the concept of Total Institution and defines it as:

"[...] A place of residence or work where a large number of individuals with a similar situation, separated from the larger society for a considerable period of time, lead a closed and formally administered life". ${ }^{36: 11}$

Goffman adds a second feature related to the segregative aspect, because when the institution restrains the internal side of contact with the outside, it imposes, in parallel, a basic division between a controlled group and a controlling group within it. ${ }^{36}$ On the other hand, Foucault exposes institutions as disciplinary, which aim to govern men and conduct their actions. ${ }^{3}$ It should be pointed out that Goffman describes a totalitarian institution and with total segregation of society, while Foucault describes a disciplinary institution where the subject is driven by discipline as a means of exercising relations of power, which can only be established between free subjects.

In this perspective, it is understood that the hospital, as an institution impregnated by routines, norms and hierarchies, does not totally escape these concepts. Therefore, it is possible to identify that, within the hospital, patients live their daily lives under the same authority and are conditioned to the controlled group, thus automatically positions nursing professionals in the controlling group. Based on this, it can be seen that, as an institution, the hospital produces and reproduces relations of power, a fact that corroborates Foucault's point of view, which shows a historical-genealogical conception that points to institutionalization as an instrument of consolidation and the exercise of power relations. ${ }^{3}$ Thus, the phenomenon of institutionalization could be defined as a process consisting of practices and ideologies that serve a particular context, for example, legal structures or, in the case of the hospital, its set of norms and routines. ${ }^{37}$

In spite of considering important differences in Goffman and Foucault's ideas about institutions, it is possible to find points of relation between their formulations that help to interpret the meaning of the concept and its great theoretical and political relevance ${ }^{38} \mathrm{An}$ example of this is the agreement that discipline pervades the whole context of institutions, indicating how historically a prison looks like a hospital, which in turn maintains close similarity to a military facility. From this thought comes the shock of Foucault by posing the following question: "Should we still be surprised that a prison institution resembles a factory, a school, a hospital and the barracks, and all these institutions look like a prison?"28:214

Considering the idea exposed regarding the similarity between hospitals and prisons and its relation to disciplinary methods, ${ }^{28}$ it was verified that one of the most important principles for the formation of the hospital institution, as it is known today, was the composition of a space that would allow the total visibility of the bodies of individuals and things in order to obtain a centralized view, thus constituting a space for 
disciplinarization, ${ }^{38}$ where patients' freedom and autonomy will constantly be affected, as can be seen in the allegations of the participants of this research:

[...] What I feel is a feeling of loss, abandonment, hopelessness, imprisonment! (P3);

I don't have any freedom here in the hospital [...] I keep asking God to be healed and get out of that cage (P5);

[...] I felt trapped, I had no right to arrive at the post [...] I could not do anything, because I kept my hands tied... I felt like a trapped animal (P7);

There I cannot do what I want to do [...] that place means suffering, humiliation, sadness; it is everything $[\ldots](P 16)$.

It should be pointed out that this commitment to patients' freedom is not only due to the disciplinary or segregative character of the hospital institution, as seen previously, but also due to the dependence that the illness and hospitalization situation causes, because the greater the degree of dependence on nursing care, the smaller the space for patient autonomy, and the more evident is the asymmetric relationship of power. ${ }^{39}$ Thus, it can be seen that power relations are present not only in the way the institution operates, but it confirms Foucault's idea on the micro-powers and their ability to penetrate everyday life, since they do not exert themselves above anything but at the level of the body, reaching it and controlling its conduct and behavior, ${ }^{28}$ as can be seen in the following statements:

[...] I had my freedom because I would go where I wanted and now I can't [...] I depend on others; it is not good (P2);

I'll tell you, here we feel that we lose our freedom [...] you have to leave everything, right? We depend too much on others [...] (P4);

They are tired of saying that the obligation to give me a bath is theirs, even if I prefer that my daughter gives me a bath $[\ldots]$ (P8)

Other equally significant statements refer to the control exercised by professionals, consciously or not, justified by their knowledge:

I showered in the bathroom, but as I can't move my legs, they decided that I had to take a shower in bed... I felt bad because I like to take a shower in the shower! (P12);

[...] I was trapped inside the room for six days; I couldn't go out [...] it's like being a baby again, you need a person to take care of you, you need a person who does things for you; you're not so autonomous anymore! (P14).
At this juncture, the control here approached occurs by the observance of the aspects that involve the disciplinary regime, composed of coercion techniques such as the delimitation of space, movement, gestures, conduct and behavior. For this, discipline, as technique of the exercise of power, will use the examination that Foucault describes as, among other things, "a permanent surveillance that allows individuals to be distributed, judged, measured, localized and therefore utilized to the maximum",. 3:182 making them docile, passive and manipulable, in other words submissive bodies.

\section{CONCLUSION}

Research has shown how the power that practitioners exercise in the name of their knowledge is revealed in the participants' speeches, which allows them to say what needs to be done, to command and control compliance with the prescriptions; after all, everything they do is seen as being to help in the treatment, to hasten the cure, for the good of the people, as the powerknowledge generates a discourse with a truth value, in other words, the general thought seems to be that the ends justify the actions that precede them, since these actions are little questioned.

In this condition, the power of professional knowledge is revealed when their action is justified, because "they know what they do" when "they command" us to do what they think needs to be done and the cycle closes when "they control" the prescriptions, the orders that derive from institutional regulations and the actions that the patients themselves must carry out for their good, for their quickest recovery, constituting themselves in the form of "pastoral power", that is, the power to assist by means of professional knowledge (Emphasis of the authors).

However, the exercise of the care power must be based on the observance of ethical and bioethical principles, since the fact that the professional uses his knowledge to promote the patient's health puts him in a position of social responsibility. Therefore, it should not only do what its technical-scientific knowledge allows, but also foster a space for dialogue with the patient, allowing the patient to exercise his autonomy and position himself more actively in the face of power coming from the knowledge of nursing professionals. Thus, in order to promote the real objective of power relations, which Michel Foucault believed to be a space for the exchange of the exercise of the binomial power-freedom, where one is the basis for the existence of the other.

It is known that this study used the patient's discourse as a means of understanding this side of the care relationship and, at this juncture, it is stressed that there is a need to understand, also, the discourse of nursing professionals, in order to better understand the difficulties that the hectic hospital routine imposes on these professionals. This would allow greater reflections on the subject and could provide more symmetry to the nursing care relationships, through the valorization of the contribution of both sides of the professional-patient relationship, for the reestablishment of health. 


\section{REFERENCES}

1. Ministério da Saúde (BR). Lei no 7.498 , de 25 de junho de 1986. Dispõe sobre a regulamentação do exercício da Enfermagem e dá outras providências. Brasília (DF): Diário Oficial da República Federativa do Brasil; 1986.

2. Ministério da Saúde (BR). Resolução COFEN - 311/2007. Aprova a reformulação do Código de Ética dos Profissionais de Enfermagem. Brasília (DF): Ministério da Saúde; 2007.

3. Foucault M. Microfísica do Poder. $2^{2}$ ed. Rio de Janeiro: Paz e Terra; 2015.

4. Foucault M. O Sujeito e o Poder. In: Rabinow P, Rabinow H, orgs. Michel Foucault: uma trajetória filosófica (para além do estruturalismo e da hermenêutica). Rio de Janeiro: Forense Universitária; 2012. p. 231-49.

5. Santos RM, Viana IRMN, Silva JR, Trezza MCSF, Leite JL. A enfermeira e a nudez do paciente. Rev Bras Enferm [Internet]. 2010 Nov/Dec; [cited 2016 Mar 29]; 63(6):877-86. Available from: http://www.scielo.br/scielo. php?script=sci_arttext\&pid=S0034-71672010000600002\&Ing=en\&nr m=iso. http://dx.doi.org/10.1590/S0034-71672010000600002

6. Foucault M. O Nascimento da Clínica. $7^{\underline{a}}$ ed. Col. Campo Teórico. Rio de Janeiro: Forense Universitária; 2012.

7. Henriques RTM, Cabana MCF. O Acompanhante no processo de hospitalização. Humanae [Internet]. 2013; [cited 2016 Mar 29]; 7(1):111. Available from: http://humanae.esuda.com.br/index.php/humanae/ article/view/69/62

8. Scochi CGS, Munari DB, Gelbcke FL, Erdmann AL, Gutiérrez MGR, Rodrigues RAP. Pós-graduação Strictu Sensu em Enfermagem no Brasil: avanços e perspectivas. Rev Bras Enferm [Internet]. 2013; [cited 2016 Mar 29]; 66(spe):80-9. Available from: http://www.scielo.br/pdf/ reben/v66nspe/v66nspea11.pdf. http://dx.doi.org/10.1590/S003471672013000700011

9. Almeida NMS. Formação do enfermeiro e reorientação do modelo de assistência à saúde: um estudo cartográfico. [Dissertação de mestrado]. Jequié (BA): Universidade Estadual do Sudeste da Bahia; 2012.

10. Carvalho SORM, Budó MLD, Silva MM, Alberti GF, Simon BS. "Com um pouco de cuidado a gente vai em frente: vivências de pessoas com estomia. Texto Contexto-Enferm [Internet]. 2015 Jan/Mar; [cited 2016 Mar 29]; 24(1):279-87. Available from: http://www.scielo.br/ pdf/tce/v24n1/pt_0104-0707-tce-24-01-00279.pdf. http://dx.doi. org/10.1590/0104-07072015003710013

11. Oliveira NES, Oliveira LMAC, Lucchese R, Alvarenga GC, Brasil VV. Humanização na teoria e na prática: a construção do agir de uma equipe de enfermeiros. Rev Eletr Enferm [Internet]. 2013 Apr/Jun; [cited 2016 Mar 29]; 15(2):334-43. Available from: https://www.fen.ufg. br/fen_revista/v15/n2/pdf/v15n2a04.pdf. http://dx.doi.org/10.5216/ree. v15i2.17916

12. Morais GSN, Costa SFG, Carneiro AD, França JRFS, Nóbrega MML, Duarte MCS. Produção Científica Sobre a Teoria Humanística da Enfermagem: revisão integrativa. Ver Enferm UFPE On Line [Internet]. 2014 Jan; [cited 2016 Mar 29]; 8(1):137-45. Available from: http://www. revista.ufpe.br/revistaenfermagem/index.php/revista/article/view/4810/ pdf_4448

13. Santos BP, Schwartz E, Beuter M, Muniz RM, Echevarría-Guanilo ME, Viegas AC. Consequências atribuídas ao transplante renal: técnica dos incidentes críticos. Texto Contexto- Enferm [Internet]. 2015; [cited 2016 Mar 29]; 24(3):748-55. Available from: http://www.scielo.br/pdf/ tce/2015nahead/pt 0104-0707-tce-2015000270014.pdf. http://dx.doi. org/10.1590/0104-07072015000270014

14. Mendes KDS, Roza BA, Barbosa SFF, Schirmer J, Galvão CM. Transplante de órgãos e tecidos: responsabilidades do enfermeiro. Texto Contexto-Enferm [Internet]. 2012 Oct/Dec; [cited 2016 Mar 29]; 21(4):945-53. Available from: http://www.scielo.br/pdf/tce/v21n4/27. pdf. http://dx.doi.org/10.1590/S0104-07072012000400027
15. Queirós PJP. Reflexões para uma epistemologia da enfermagem Texto Contexto-Enferm [Internet]. 2014 Jul/Sep; [cited $2016 \mathrm{Mar}$ 29]; 23(3):776-81. Available from: http://www.scielo.br/scielo. php?script=sci_arttext\&pid=S0104-07072014000300776\&Ing=en\&n rm=iso. http://dx.doi.org/10.1590/0104-07072014002930013

16. Santos LN, Martins A. A originalidade da obra de George Groddeck e algumas de suas contribuições para o campo da saúde. Interface (Botucatu) [Internet]. 2013 Jan/Mar; [cited 2016 Mar 29]; 17(44):921. Available from: http://www.scielo.br/scielo.php?script=sci arttext\&pid=S1414-32832013000100002\&lng=en\&nrm=iso. http:// dx.doi.org/10.1590/S1414-32832013000100002

17. Collière MF. Promover a Vida. Lisboa: Lidel; 1999.

18. Lima CA, Oliveira APS, Macedo BF, Dias OV, Costa SM. Relação profissional-usuário de saúde da família: perspectiva da bioética contratualista. Rev Bioét [Internet]. 2014 Jan/Apr; [cited 2017 Jul 19]; 22(1):152-60. Available from: http://www.scielo.br/scielo. php?script=sci_arttext\&pid=S1983-80422014000100017.http://dx.doi. org/10.1590/S1983-80422014000100017

19. Illich I. A expropriação da saúde: nêmesis da medicina. $3^{a}$ ed. Rio de Janeiro: Nova Fronteira; 1975.

20. Stein-Pasbury J. Patient and Person: Interpersonal Skills in Nursing. $5^{\text {a }}$ ed. Chatswood: Elsevier, 2014.

21. Weiss SA, Tappen RM. Essentials of Leadership and Management 6th ed. Philadelphia (PA): F.A. Davis Company; 2015.

22. Foucault M. Ética, Estratégia, Poder-Saber. Ditos \& Escritos IV. Vol. IV $3^{\text {a }}$ ed. Rio de Janeiro (RJ): Forense Universitária; 2012.

23. Cassola TP, Backes DS, Ilha S, Souza MHT, Cárceres KF. Processo adaptativo dos cuidadores de uma pessoa idosa com alzheimer: contribuições da Enfermagem. Rev Enferm UFPE On Line (Recife) [Internet]. 2014 Jul; [cited 2017 Jul 19]; 8(supl.1):2243-8. Available from: http://www.revista.ufpe.br/revistaenfermagem/index.php/revista/ article/viewFile/5319/pdf_5620

24. Silva GF, Machado Júnior SS. O Discurso em Michel Foucault. Rev Eletr Hist Refl. 2014;8(16):1-14.

25. Foucault M. A Ordem do Discurso. 24ํㅡㄹ ed. São Paulo: Edições Loyola 2014.

26. Perroca MG, Gaidzinski RR. Sistema de classificação de pacientes: construção e validação de um instrumento. Rev Esc Enferm USP [Internet]. 1998 Aug; [cited 2017 Jul 19]; 32(2):153-68. Available from: http://www.scielo.br/scielo.php?script=sci_arttext\&pid=S0080$62341998000200009 \&$ Ing=en. http://dx.doi.org/10.1590/S008062341998000200009

27. Foucault M. Power (The Essential Works of Foucault 1954-1984 vol. 3). London: Penguin Books; 2002.

28. Foucault M. Vigiar e Punir: Nascimento da Prisão. 41a ed. Petróplis: Vozes; 2013.

29. Foucault M. A Arqueologia do Saber. $8^{a}$ ed. Rio de Janeiro: Forense Universitária; 2012

30. Ardigo FS, Amante LN. Conhecimento do profissional acerca do cuidado de Enfermagem à pessoa com estomia. Texto ContextoEnferm [Internet]. 2013 Oct/Dec; [cited 2016 Mar 29]; 22(4):1064-71. Available from: http://www.scielo.br/pdf/tce/v22n4/24.pdf. http://dx.doi. org/10.1590/S0104-07072013000400024

31. Pessoa NRC, Linhares FMP. Pacientes em hemodiálise com fístula arteriovenosa: conhecimento, atitude e prática. Esc Anna Nery [Internet]. 2015; [cited 2016 Mar 29]; 19(1):73-9. Available from: http:// www.scielo.br/pdf/ean/v19n1/1414-8145-ean-19-01-0073.pdf. http:// dx.doi.org/10.5935/1414-8145.20150010

32. Aguiar JM, D'Oliveira AFPL, Schraiber LB. Violência institucional, autoridade médica e poder nas maternidades sob a ótica dos profissionais de saúde. Cad Saúde Pública [Internet]. 2013 Nov; [cited 2016 Mar 29]; 29(11):2287-96. Available from: http://www.scielo.br/pdf/ csp/v29n11/15.pdf. http://dx.doi.org/10.1590/0102-311x00074912 
33. Bittencourt ALP, Quintana AM, Velho MTAC, Goldim JR, Wottrich LAF, Cherer EQ. A voz do paciente: por que ele se sente coagido? Psicol Est [Internet]. 2013 Jan/Mar; [cited 2016 Mar 29]; 18(1):93-101. Available from: http://www.scielo.br/pdf/pe/v18n1/v18n1a09.pdf. http://dx.doi. org/10.1590/S1413-73722013000100010

34. Foucault M. Arqueologia das Ciências, História dos Sistemas de Pensamento. Ditos \& Escritos II. Vol. II, $3^{3}$ ed. Rio de Janeiro: Forense Universitária; 2013.

35. Ribeiro JCS, Dacal MDPO. A instituição hospitalar e as práticas psicológicas no contexto da Saúde Pública: notas para reflexão. Rev SBPH [Internet]. 2012 Jul/Dec; [cited 2016 Mar 29]; 15(2):65-84. Available from: http://pepsic.bvsalud.org/pdf/rsbph/v15n2/v15n2a06.pdf
36. Goffman E. Manicômios, Prisões e Conventos. 9ª ed. São Paulo: Perspectiva; 2015

37. Silveira RA. Michel Foucault: Poder e análise das organizações. $1^{\underline{a}} \mathrm{ed}$. Rio de Janeiro: Editora FGV; 2005.

38. Sasso ES. Princípios operadores disciplinares e a resistência contra a sujeição: uma perspectiva foucaultiana. [Dissertação de mestrado] Guarulhos (SP): Universidade Federal de São Paulo; 2014.

39. Delmar C. The excesses of care: a matter of understanding the asymmetry of power. Nurs Philos [Internet]. 2012 Oct; [cited 2016 Mar 29]; 13(4):236-43. Available from: https://www.researchgate.net/ publication/230803439

a Article extracted from the dissertation titled: "Power in nursing care relations: the patient's voice" defended in the Graduate Program in Nursing of the Federal University of Alagoas and it was funded by CAPES in the form of a scholarship, Maceió, 2016.

${ }^{\mathrm{b}}$ The studies examined to close the search for participants were carried out in 2004 and 2008, addressing aspects of the problem addressed in this research, respectively: Pereira, W.R. Poder, violência e dominação simbólicas nos serviços públicos de saúde. Texto Contexto Enferm. 2004; 13(3):334-340 e Santos, J.O.; Shimo, A.K.K. Prática rotineira da Episiotomia refletindo a desigualdade de poder entre profissionais de saúde e mulheres. Esc Anna Nery Enferm. 2008 12(4):645-650. 